\title{
Fatty acid partitioning varies across fillet regions during sexual maturation in female rainbow trout (Oncorhynchus mykiss)
}

\author{
Beth M. Cleveland $^{\mathrm{a}, *}$, Gregory M. Weber ${ }^{\mathrm{a}}$, Susan K. Raatz ${ }^{\mathrm{b}}$, Caird E. Rexroad ${ }^{\mathrm{a}}$, Matthew J. Picklo ${ }^{\mathrm{b}}$ \\ a National Center for Cool and Cold Water Aquaculture, USDA/ARS, 11861 Leetown Rd, Kearneysville, WV 25430, United States \\ ${ }^{\mathrm{b}}$ Grand Forks Human Nutrition Research Center, USDA/ARS, 2420 2nd Avenue North, Grand Forks, ND 58203, United States
}

\section{A R T I C L E I N F O}

\section{Article history:}

Received 4 November 2016

Received in revised form 16 February 2017

Accepted 6 March 2017

Available online 18 March 2017

\begin{abstract}
A B S T R A C T
Rainbow trout (Oncorhynchus mykiss) are commonly reared as diploids (2N, two sets of chromosomes) or triploids ( $3 \mathrm{~N}$, three sets of chromosomes). Sexual maturation in $2 \mathrm{~N}$ has negative effects on production efficiency, nutrient retention, and fillet quality. On the other hand, $3 \mathrm{~N}$ female rainbow trout fail to develop gonads, thus enabling an efficient extended growth period when production of larger fillets is desired. The objective of this study was to determine how fatty acid (FA) profiles of various tissue types change throughout development in $2 \mathrm{~N}$ and $3 \mathrm{~N}$ rainbow trout, with an emphasis on the response of different fillet regions. Diploid and $3 \mathrm{~N}$ female rainbow trout were comingled and harvested at 10, 18, and 22 months post hatch (mph) and FA profiles of the viscera, fillet sections, and fillet trimmings were analyzed. Diploid fish were larger $(P<0.05)$ than $3 \mathrm{~N}$ at all sampling periods. Fillet yield was similar between $2 \mathrm{~N}$ and $3 \mathrm{~N}$ at 10 and $18 \mathrm{mph}$, while fillet yield was greater in $3 \mathrm{~N}$ at $22 \mathrm{mph}(P<0.05)$. Fillets were divided into four sections; ventral, central, dorsal and caudal. In the ventral, dorsal, and caudal fillets, FAs continued to accumulate with age $(P<0.05)$, regardless of ploidy. However, in the $2 \mathrm{~N}$ ventral fillet the rate of muscle growth outpaced deposition of saturated FAs between 18 and $22 \mathrm{mph}(P<0.05)$. In the $2 \mathrm{~N}$ central fillet the concentration of most FAs decreased between 18 and $22 \mathrm{mph}(P<0.05)$ while they continued to increase in $3 \mathrm{~N}$. A similar interaction occurred in viscera tissue, in which there was no net accumulation of FAs in $2 \mathrm{~N}$ between 18 and $22 \mathrm{mph}$ while $3 \mathrm{~N}$ continued to deposit FA. Saturated FAs were most susceptible to reduced concentrations during sexual maturation, suggesting an increased reliance upon these lipids as a source of energy to support gonad development. In conclusion, there was a disproportionate mobilization of FAs both across and within tissues, with lipids in the viscera and central fillet being particularly vulnerable to mobilization during sexual maturation.
\end{abstract}

Published by Elsevier B.V.

\section{Introduction}

Rainbow trout (Oncorhynchus mykiss) are produced as both diploids ( $2 \mathrm{~N}$, two sets of chromosomes) and triploids (3N, three sets of chromosomes). Triploid rainbow trout are sterile and while males develop testes that produce nonviable milt, females exhibit a near absence of gonadal development (Lincoln and Scott, 1983). The sterility of the $3 \mathrm{~N}$ trout, particularly the female $3 \mathrm{~N}$, provides several advantages for aquaculture production, including 1 ) prevention of native or conspecific species from mating with stocked or escaped fish, 2) protection of proprietary germplasm from propagation for seed companies, and 3 ) the ability to produce large fillets without compromising flesh quality. Dramatic increases in gonad weight from $<2 \%$ up to $20 \%$ of total body weight occurs between 18 and 22 months post hatch ( $\mathrm{mph}$ ) in sexually

\footnotetext{
* Corresponding author at: NCCCWA, 11861 Leetown Rd, Kearneysville, WV 25430, United States.

E-mail address: beth.cleveland@ars.usda.gov (B.M. Cleveland).
}

maturing $2 \mathrm{~N}$ female rainbow trout. During this period of sexual maturation, specific growth rate decreases (Tveranger, 1985; Weber et al., 2014), as does fillet yield and fillet quality in terms of texture and lipid content (Aussanasuwannakul et al., 2011; Manor et al., 2014). Therefore, the absence of gonad development in the female $3 \mathrm{~N}$ rainbow trout allows for uninterrupted growth performance past the age at which $2 \mathrm{~N}$ begin to sexually mature, enabling production of larger, high-quality rainbow fillets.

Given adequate nutrient intake, viscera adipose tissue and muscle lipids will increase in concentration as the fish grows. However, sexual maturation is an energy-intensive process and occurs at the expense of endogenous lipid and protein stores. Lipids are preferentially mobilized from viscera adipose tissue, even if the fish is at a satiable level of feed intake (Cleveland et al., 2012; Jonsson et al., 1997; Manor et al., 2014). Reductions in muscle lipid content can also occur during sexual maturation, but this response is alleviated with adequate energy and nutrient consumption (Cleveland et al., 2012; Washburn et al., 1990). In contrast, dorsal fat deposits and lipid content in red muscle remain stable during sexual maturation (Kiessling et al., 1991, 2001). 
Previous findings have determined how the fatty acid (FA) profiles within different tissue types change in $2 \mathrm{~N}$ rainbow trout due to sexual maturation. Findings largely support that rather than the nondiscriminatory mobilization of all FA, saturated and certain unsaturated FA types are selectively sequestered from muscle and viscera tissue to support processes associated with sexual maturation and gonad development (Manor et al., 2014, 2012; Ribeiro et al., 2012). While saturated FAs (SFA) and monounsaturated (MUFA) are likely the preferred substrates for $\beta$-oxidation and may be particularly valuable to support energy-intensive maturation-related processes like vitellogenesis, polyunsaturated FAs (PUFA) may be more valuable as essential components for oocyte health and embryo development (Ribeiro et al., 2012; reviewed in Tocher, 2003).

Previous studies have identified changes in skeletal muscle lipid profiles on the basis of the muscle as one unit. However, lipid concentrations are not uniform across the fillet, and in fact vary considerably across skeletal muscle. In several fish species, including salmonids, lipid concentrations in the ventral portion of the fillet can be twice that of the dorsal and central regions, and three times higher than the caudal region of the fillet (Katikou et al., 2001; Kinsella et al., 1977; Palmeri et al., 2007; Testi et al., 2006; Toussaint et al., 2005). Fatty acid profiles also vary with location, for example, in cod SFAs remain fairly consistent across sections whereas unsaturated FA ratios are more variable (Palmeri et al., 2007). Although variations in FA profiles across fillet regions in wildcaught lake trout have been described (Kinsella et al., 1977), this information has only been reported in rainbow trout for the dorsal half versus the ventral half of the fillet (Testi et al., 2006). It is unknown how the FA profile within each section responds to lipid repartitioning during sexual maturation.

Dietary intake of fish is associated with reduced incidence of cardiovascular disease (Albert et al., 1998; Burr et al., 1989; Daviglus et al., 1997; Kris-Etherton et al., 2003a, b). There is strong support for a role of long chain n-3 polyunsaturated fatty acids ( $n-3$ LCPUFA) in this response (Calder, 2006, 2010; Vykoukal and Davies, 2011), suggesting consumption of farmed fish with high fillet n-3 LCPUFA concentrations, such as rainbow trout (Blanchet et al., 2005), are particularly beneficial for cardiovascular health. Therefore, understanding how fillet FAs, including n-3 LCPUFA, change in rainbow trout throughout development is important to identify production practices and post-harvesting processing methods that yield fillet products with optimal lipid profiles and health benefits.

The objective of this study was to determine how the FA profile of different tissues, including various regions of the fillet, change throughout development in sexually maturing $2 \mathrm{~N}$ and sterile $3 \mathrm{~N}$ female rainbow trout.

\section{Material and methods}

\subsection{Fish husbandry}

Fish were raised at the USDA, ARS, National Center for Cool and Cold Water Aquaculture (NCCCWA, Kearneysville, WV). Procedures and protocols involving live fish received approval from the NCCCWA Animal Care and Use Committee (IACUC) and were performed according to IACUC guidelines (protocol \#080). Water alternated between flowthrough and partial reuse $(<30 \%)$ and temperatures ranged between 12.0 and $13.5^{\circ} \mathrm{C}$. All tanks were indoors with artificial lighting that mimicked ambient photoperiod. A commercially available feed (Finfish G, $42 \%$ protein $/ 16 \%$ fat by weight, Zeigler Bros, Inc., Gardners, PA) was provided using an automated feeding system (ArvoTec, Finland) that provided feed daily in numerous doses between the hours of 10:0014:30. Fish were provided feed at or just below satiation for the entire grow-out period. The lipid profile of the diet is provided in Supplementary File 1.

\subsection{Experimental design}

Fish used in this study were part of a larger population of $2 \mathrm{~N}$ and $3 \mathrm{~N}$ rainbow trout used for additional studies. A total of 18 all-female full-sib families were produced and half of each family was induced by pressure shock to produce $3 \mathrm{~N}$ and were confirmed as $2 \mathrm{~N}$ or $3 \mathrm{~N}$ by flow cytometry (Allen, 1983; Hershberger and Hostuttler, 2007). Family associations were considered to minimize effects due to differences in genetics among treatments. At $30 \mathrm{~g}, 150$ fish from each family were PIT tagged and fish were equally comingled among three tanks $\left(1.7 \mathrm{~m}^{3}\right)$. Fish were weighed individually and fork lengths recorded every four weeks. Fish were culled periodically to maintain acceptable biomass $(\leq 80 \mathrm{~kg} / \mathrm{m} 3)$. At approximately 1 year post-hatch fish were transferred to three larger triplicate tanks $\left(\mathrm{n}=3,3 \mathrm{~m}^{3}\right)$ where they remained for the duration of the study. Three unrelated families were identified and six fish per family ( 3 per ploidy) were removed from each tank at 10 , 18 , and 22 months post hatch for analysis of lipid profiles. The same families were targeted for each sampling period. Feed was withheld the day of each sampling. Fish were anesthetized with tricaine methanesulfonate (MS222, Western Chemical, Ferndale, WA) at $100 \mathrm{mg} / \mathrm{L}$ during all handling events. An overdose of MS222 $(>200 \mathrm{mg} / \mathrm{L})$ was used for euthanizing fish.

Whole body weights were collected from each fish. The viscera, including the liver, gastrointestinal tract, and adipose tissue were removed and collectively weighed. Gonads were removed, weighed, and discarded. The butterfly fillet was separated from the carcass. The belly flap and dorsal trimmings were removed from the butterfly fillet and weighed separately (Fig. 1a). The skin was removed from each fillet and the right fillet was divided into four sections (Fig. 1b). Each fillet section was weighed and stored separately. Ultimately, a total of seven tissue groups were analyzed from each fish for its lipid profile; 1) dorsal fillet, 2) central fillet, 3) ventral fillet, 4) caudal fillet, 5) viscera, 6) belly flap, and 7) dorsal trimmings. Tissues were stored in separate bags at $-80^{\circ} \mathrm{C}$ until analysis.

\subsection{Lipid analysis}

Lipids were extracted from fillet samples based on the methods described in Folch et al. (1957). Samples (approximately $5 \mathrm{~g}$ ) were pulverized at liquid nitrogen temperature and the resulting powder stored at $-80{ }^{\circ} \mathrm{C}$ until extraction. Approximately $50 \mathrm{mg}$ of the pulverized samples were weighed into glass test tubes that were kept cold in liquid nitrogen. $2.5 \mathrm{~mL}$ of Folch solution (chloroform: methanol, 2:1 v/v, containing $50 \mu \mathrm{M}$ butylated hydroxytoluene (BHT)) and $0.5 \mathrm{~mL} 0.9 \%$ potassium chloride with $100 \mu \mathrm{M}$ diethylenetriaminepentaacetic acid (DTPA) was added to the samples. The samples were vortexed for $30 \mathrm{~s}$ and placed on a vertical rotator overnight (approximately $16 \mathrm{~h}$ ). During method development we observed that while extraction of long chain PUFA was complete within 2 , an overnight incubation was needed to improve the recovery of saturated FAs. After the extraction, the samples were centrifuged at $2000 \times \mathrm{g}$ for $10 \mathrm{~min}$ at room temperature. The bottom layer was removed and placed in a new test tube. The remaining upper layer was re-extracted by the addition of $2.5 \mathrm{~mL}$ of Folch solution
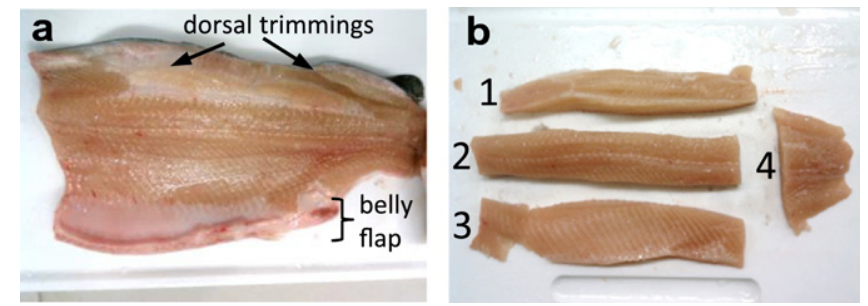

Fig. 1. Sectioning the fillet trimmings and the fillet for FA profiling. a) Dorsal trimmings and belly flap removed prior to fillet sectioning. b) Four sectional cuts analyzed for FA profiling: 1) dorsal, 2) central, 3) ventral, 4) caudal. 
followed by homogenization for $30 \mathrm{~s}$ and centrifugation at $2000 \times \mathrm{g}$ for $10 \mathrm{~min}$ at room temperature. The lower layer was removed and combined with the previous extracted lower layer. The samples were dried down under nitrogen and reconstituted in $2 \mathrm{~mL}$ of hexane: isopropanol 3:2 v/v with $50 \mu \mathrm{M}$ BHT and 5\% deionized water. Samples were stored at $-20{ }^{\circ} \mathrm{C}$ until fatty acid methyl ester (FAME) analysis.

Viscera samples were thawed on ice and weighed. BHT was added to a final concentration of $50 \mu \mathrm{M}, 1 \mathrm{~mL}$ of $50 \mathrm{mM}$ BHT (in methanol) per $1 \mathrm{~kg}$ viscera. Due to the heterogenous physical nature of the visceral contents, samples were homogenized in one of two homogenizers. Samples larger than $50 \mathrm{~g}$ were processed in Vitamix 5200 (Vita-mix Corp., Cleveland, $\mathrm{OH}$ ). Samples under $50 \mathrm{~g}$ were processed in Braun Grinder type 4041 (Braun GmbH, Germany). After homogenization, $10 \mathrm{~mL}$ portions of homogenate were aliquoted into $15 \mathrm{~mL}$ plastic conical tubes and stored at $-80^{\circ} \mathrm{C}$. Because of the substantial separation of the lipid fraction in the homogenate, we chose to use a lipid extraction procedure designed for visceral samples based upon the method of $\mathrm{Wu}$ and Bechtel (2008). Homogenates were thawed at room temperature and incubated in a water bath at $92{ }^{\circ} \mathrm{C}$ for $15 \mathrm{~min}$. During the incubation, samples were gently vortexed to remove air bubbles that collected within the homogenate. Samples were centrifuged at $2000 \times \mathrm{g}$ for $17 \mathrm{~min}$ at room temperature. The top oil layer was transferred to a new test tube. The weights of the oil layer and the remaining aqueous layer were recorded. Approximately $25 \mathrm{mg}$ of the oil layer was transferred into a $12 \mathrm{~mL}$ glass test tube and diluted with $5 \mathrm{~mL}$ of hexane. $0.2 \mathrm{~mL}$ of this diluted oil solution was used for FAME analysis.

Fatty acids were converted to fatty acid methyl esters (FAME) in the presence of acetyl chloride and analyzed by gas chromatography with flame ionization detection (GC-FID) as described previously (Picklo and Murphy, 2016). Nonadecanoic acid was used as an internal standard for quantitation. FAME calibrants and nonadecanoic acid were purchased from Nu-Chek Prep. Inc., Elysian, MN. GC was performed on a Thermo Trace-1310 equipped with a TriPlus RSH Autosampler, (Thermo Fisher Scientific, Waltham, MA, USA) and a Supelco SP-2560 capillary column ( $75 \mathrm{~m}, 0.18 \mathrm{~mm}$ ID, $0.14 \mu \mathrm{m}$ film thickness. Samples were injected into a split/splitless injector held at $250{ }^{\circ} \mathrm{C}$ with a hydrogen carrier gas running at a column flow of $2 \mathrm{~mL} / \mathrm{min}$ with a 100:1 split. The oven temperature profile was (1) $150{ }^{\circ} \mathrm{C}$ held for $0.25 \mathrm{~min}$, (2) ramped at $35{ }^{\circ} \mathrm{C} /$ min to $200{ }^{\circ} \mathrm{C}$, then (3) ramped at $8{ }^{\circ} \mathrm{C} /$ min to $225^{\circ} \mathrm{C}$, held at $225{ }^{\circ} \mathrm{C}$ for $3.20 \mathrm{~min}$ followed by (4) an $80{ }^{\circ} \mathrm{C} / \mathrm{min}$ ramp to $245{ }^{\circ} \mathrm{C}$, where the oven was held for $4 \mathrm{~min}$. All data were acquired and analyzed using a Dionex Chromeleon 7.2 Chromatography data system (Thermo Fisher Scientific, Waltham, MA, USA). All automatic peak assignments and integrations were manually verified.

\subsection{Statistics}

Data were analyzed by analysis of variance PC-SAS Software (Version 9.2). Main effects of ploidy, age, and a ploidy $*$ age interaction were detected and determined as significant when $P<0.05$. Variation due to family was accounted for by identifying family as a class variable. When a significant ploidy $*$ age interaction occurred, differences between treatment groups were detected using pair-wise comparison between LSmeans. Differences in growth and FA accumulation between
18 and $22 \mathrm{mph}$ were identified using Student's $t$-test analysis for which $P<0.05$ was used to identify means that differ. Data are presented as means \pm SEM.

\section{Results}

\subsection{Body weight and morphometrics}

Body weights and morphometric measurements of fish harvested for FA analysis are shown in Table 1 . Although whole body weight (WBW) was similar between $2 \mathrm{~N}$ and $3 \mathrm{~N}$ at $10 \mathrm{mph}$, WBW was greater in $2 \mathrm{~N}$ fish at 18 and $22 \mathrm{mph}$. Eviscerated body weight (EvBW), although greater in $2 \mathrm{~N}$ fish at 18 months, was not different between $2 \mathrm{~N}$ and $3 \mathrm{~N}$ at $22 \mathrm{mph}$. Gonad development in $2 \mathrm{~N}$ was evident as an increasing gonadal somatic index (GSI) from 18 to $22 \mathrm{mph}$, while 3N exhibited a near absence of gonad growth. Fillet yield and viscera yield, as a percent of EvBW, was similar in $2 \mathrm{~N}$ and $3 \mathrm{~N}$ at 10 and $18 \mathrm{mph}$, but significantly higher in $3 \mathrm{~N}$ at $22 \mathrm{mph}$. Viscera yield was least in $2 \mathrm{~N}$ at $22 \mathrm{mph}$.

\subsection{FA profiles within fillet sections}

The FA profiles for each region of the fillet, in terms of total FAs, total saturated FA (SFA), total monounsaturated FA (MUFA), total polyunsaturated FA (PUFA), and n-3 LCPUFA (the sum of eicosatrienoate, 20:3n-3, eicosapentaenoic acid, 20:5n-3, docosapentaenoate, 22:5n-3, and docosahexaenoic acid, 22:6n-3) are shown in Table 2. The complete FA profiles for each section are presented in Supplementary Files 2-5. Individual FAs that exhibited $P<0.10$ for a main effect of ploidy, age, or ploidy $*$ age are shown in heat maps in Fig. 2 .

Total FA, SFA, MUFA, and PUFA concentrations increased with age in the dorsal, ventral, and caudal fillet sections (Table 2, Fig. 2). In contrast, the central fillet demonstrated a significant interaction between ploidy and age for all FA groups, including n-3 LCPUFA. In the 3N central fillet, FA concentrations increased with age, reaching highest levels in the oldest fish ( $22 \mathrm{mph}$ ). However, in the $2 \mathrm{~N}$ central fillet FA concentrations decreased between 18 and $22 \mathrm{mph}$ to reach levels comparable to $10 \mathrm{mph}$ values. This response occurred for 22 of the 26 FAs detected (Supplementary File 3).

Biomass continued to increase, even in sexually maturing $2 \mathrm{~N}$, so the fold change in tissue and FA biomass from 18 to $22 \mathrm{mph}$ was determined for each fillet section (Fig. 3a-f). In $3 \mathrm{~N}$ fish, the biomass of each fillet section, as well as the cumulative fillet, increased between 1.5 and 2.0 fold, and for most sections this was a faster rate than was observed in $2 \mathrm{~N}$ (1.2-1.7 fold increase) (Fig. 3a). The accumulation of total FA, SFA, MUFA, PUFA and n-3 LCPUFA during the 18 to $22 \mathrm{mph}$ growth period was greater in $3 \mathrm{~N}$ ventral (with the exception of PUFA, $P=0.068$ ) and central fillets (Fig. 3b-f) compared to the $2 \mathrm{~N}$. However, dorsal and caudal fillet sections accumulated FAs at a similar rate between $3 \mathrm{~N}$ and $2 \mathrm{~N}$ (Fig. 3b-f). Also notable was that, in the $3 \mathrm{~N}$ central fillet, total FA gain ( 3.0 fold) exceeded biomass gain (2.0 fold) (Fig. 3a,b) and this observation is consistent with increased FA concentrations from 18 to $22 \mathrm{mph}$ (Table 2). In contrast, there was little to no lipid accumulation (0.9-1.1 fold) from 18 to $22 \mathrm{mph}$ in the $2 \mathrm{~N}$ central fillet (Fig. 3b), despite a 1.5-fold increase in central fillet weight, and this

Table 1

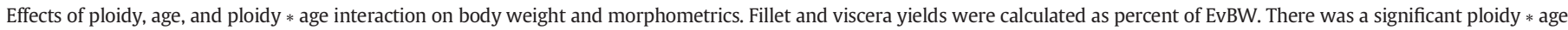
interaction for each variable $(P<0.05)$. Different letters indicate a significant difference $(P<0.05)$. Values are means \pm SEM, $\mathrm{n}=9$.

\begin{tabular}{|c|c|c|c|c|c|c|}
\hline \multirow[t]{2}{*}{ Variable } & \multicolumn{2}{|l|}{10 months } & \multicolumn{2}{|l|}{18 months } & \multicolumn{2}{|l|}{22 months } \\
\hline & $2 \mathrm{~N}$ & $3 N$ & $2 \mathrm{~N}$ & $3 N$ & $2 \mathrm{~N}$ & $3 N$ \\
\hline WBW (g) & $550 \pm 23^{f}$ & $478 \pm 18^{f}$ & $1973 \pm 100^{\mathrm{e}}$ & $1598 \pm 67^{d}$ & $3655 \pm 185^{\mathrm{a}}$ & $2880 \pm 167^{b}$ \\
\hline EvBW (g) & $501 \pm 21^{\mathrm{d}}$ & $439 \pm 17^{d}$ & $1777 \pm 92^{\mathrm{b}}$ & $1438 \pm 55^{c}$ & $2834 \pm 169^{a}$ & $2604 \pm 152^{a}$ \\
\hline GSI (\%) & - & - & $0.75 \pm 0.20^{\mathrm{b}}$ & $0.02 \pm 0.01^{\mathrm{c}}$ & $17.56 \pm 1.2^{\mathrm{a}}$ & $0.02 \pm 0.01^{\mathrm{c}}$ \\
\hline Fillet yield (\%) & $44.7 \pm 0.7^{\mathrm{b}}$ & $43.0 \pm 0.9^{\mathrm{b}}$ & $48.3 \pm 0.4^{\mathrm{a}}$ & $48.0 \pm 0.8^{\mathrm{a}}$ & $44.5 \pm 1.7^{\mathrm{b}}$ & $47.6 \pm 0.9^{\mathrm{a}}$ \\
\hline Viscera yield (\%) & $9.93 \pm 0.54^{\mathrm{ab}}$ & $8.97 \pm 0.39^{b}$ & $10.24 \pm 0.69^{\mathrm{ab}}$ & $10.96 \pm 0.73^{\mathrm{a}}$ & $6.65 \pm 0.49^{c}$ & $10.67 \pm 0.62^{a}$ \\
\hline
\end{tabular}


Table 2

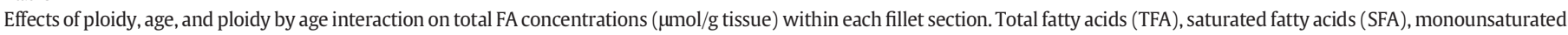

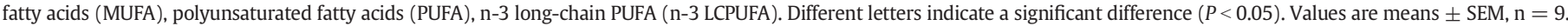

\begin{tabular}{|c|c|c|c|c|c|c|c|c|c|c|}
\hline \multirow[t]{2}{*}{ Fatty acid } & \multicolumn{2}{|c|}{10 months } & \multicolumn{2}{|c|}{18 months } & \multicolumn{2}{|c|}{22 months } & \multirow[t]{2}{*}{ Pooled SEM } & \multicolumn{3}{|l|}{$P$-value } \\
\hline & $2 \mathrm{~N}$ & $3 N$ & $2 \mathrm{~N}$ & $3 N$ & $2 \mathrm{~N}$ & $3 N$ & & Ploidy & Age & Ploidy * age \\
\hline \multicolumn{11}{|l|}{ Ventral fillet } \\
\hline TFA & 328.3 & 324.4 & 454.0 & 500.0 & 423.7 & 521.9 & 48.7 & 0.233 & 0.005 & 0.559 \\
\hline SFA & 93.9 & 90.7 & 125.5 & 139.4 & 100.8 & 138.4 & 12.4 & 0.109 & 0.008 & 0.244 \\
\hline MUFA & 108.2 & 106.0 & 168.8 & 180.9 & 160.8 & 198.3 & 19.7 & 0.322 & 0.001 & 0.584 \\
\hline PUFA & 127.1 & 128.7 & 161.0 & 181.2 & 162.7 & 185.0 & 16.7 & 0.269 & 0.015 & 0.772 \\
\hline n-3 LCPUFA & 42.4 & 42.9 & 48.6 & 53.1 & 43.6 & 52.9 & 3.9 & 0.137 & 0.113 & 0.528 \\
\hline \multicolumn{11}{|l|}{ Central fillet } \\
\hline TFA & $162.8^{\mathrm{c}}$ & $142.6^{c}$ & $230.4^{\mathrm{ab}}$ & $202.6^{\mathrm{bc}}$ & $163.0^{c}$ & $295.4^{\mathrm{a}}$ & 23.5 & 0.130 & 0.006 & 0.002 \\
\hline SFA & $48.0^{\mathrm{bc}}$ & $41.0^{c}$ & $64.2^{\mathrm{ab}}$ & $58.6^{\mathrm{b}}$ & $40.4^{c}$ & $81.7^{\mathrm{a}}$ & 6.4 & 0.062 & 0.019 & 0.001 \\
\hline MUFA & $54.2^{\mathrm{c}}$ & $46.5^{c}$ & $84.7^{\mathrm{b}}$ & $72.5^{\mathrm{bc}}$ & $60.5^{c}$ & $112.8^{\mathrm{a}}$ & 9.0 & 0.133 & 0.001 & 0.001 \\
\hline PUFA & $60.6^{\mathrm{bc}}$ & $55.2^{\mathrm{c}}$ & $81.6^{\mathrm{ab}}$ & $71.5^{\mathrm{bc}}$ & $62.1^{\mathrm{bc}}$ & $100.9^{a}$ & 8.2 & 0.222 & 0.019 & 0.007 \\
\hline n-3 LCPUFA & $19.7^{\mathrm{b}}$ & $18.4^{\mathrm{b}}$ & $23.4^{\mathrm{ab}}$ & $21.2^{\mathrm{ab}}$ & $17.7^{\mathrm{b}}$ & $26.8^{\mathrm{a}}$ & 2.0 & 0.267 & 0.164 & 0.019 \\
\hline \multicolumn{11}{|l|}{ Dorsal fillet } \\
\hline TFA & 132.8 & 101.7 & 188.5 & 205.1 & 226.3 & 208.3 & 18.9 & 0.634 & 0.001 & 0.455 \\
\hline SFA & 38.0 & 28.6 & 51.3 & 57.1 & 49.9 & 55.9 & 4.9 & 0.851 & 0.001 & 0.215 \\
\hline MUFA & 44.7 & 33.2 & 71.5 & 75.9 & 85.9 & 81.3 & 7.9 & 0.551 & 0.001 & 0.601 \\
\hline PUFA & 50.2 & 39.9 & 65.7 & 72.2 & 80.4 & 71.1 & 6.3 & 0.406 & 0.001 & 0.336 \\
\hline n-3 LCPUFA & 15.3 & 13.3 & 18.2 & 19.8 & 20.0 & 19.4 & 1.4 & 0.772 & 0.001 & 0.438 \\
\hline \multicolumn{11}{|l|}{ Caudal fillet } \\
\hline TFA & 142.7 & 156.5 & 230.5 & 258.3 & 253.3 & 219.5 & 32.1 & 0.907 & 0.005 & 0.592 \\
\hline SFA & 40.3 & 43.1 & 62.8 & 71.0 & 61.1 & 59.8 & 8.0 & 0.616 & 0.009 & 0.855 \\
\hline MUFA & 45.1 & 49.4 & 83.2 & 91.5 & 95.8 & 80.2 & 11.5 & 0.923 & 0.001 & 0.561 \\
\hline PUFA & 57.3 & 64.2 & 84.6 & 95.8 & 96.5 & 79.6 & 10.7 & 0.955 & 0.015 & 0.404 \\
\hline n-3 LCPUFA & 21.1 & 23.3 & 26.8 & 30.4 & 28.1 & 26.2 & 2.8 & 0.613 & 0.069 & 0.630 \\
\hline
\end{tabular}

Bold values indicate significance at $P$-values $<0.05$.

observation is consistent with reduced FA concentrations from 18 to $22 \mathrm{mph}$ (Table 2). In the other fillet sections, regardless of ploidy, biomass gain was comparable to FA gain. These findings support that growth of the central fillet occurs mostly as lean biomass in the maturing $2 \mathrm{~N}$ while FAs continued to accumulate proportional to biomass gain in dorsal and caudal fillet sections.

\subsection{Whole fillet FA profile}

To represent what would be available to the consumer, the FA profile of the entire fillet was calculated by combining FA concentrations from each section after accounting for differences in section weights (Table 3 ). A significant ploidy $*$ age interaction occurred for most SFA species, including myristic acid (14:0), palmitic acid (16:0), eicosanoic acid (20:0), and behenic acid (22:0), indicating the accumulation of SFAs in the fillet is interrupted by sexual maturation in $2 \mathrm{~N}$. Despite numerical reductions in several unsaturated FAs in $2 \mathrm{~N}$ between 18 and $22 \mathrm{mph}$, a significant ploidy $*$ age interaction occurred only for the minor MUFA eicosenoic acid (20:1n-9). A main effect of ploidy on eicosapentaenoic acid (EPA, $20: 5 n-3)$ indicated higher concentrations of EPA in fillets from $3 \mathrm{~N}$ fish.

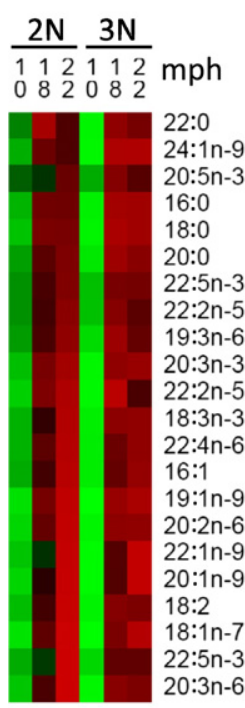

Dorsal Fillet

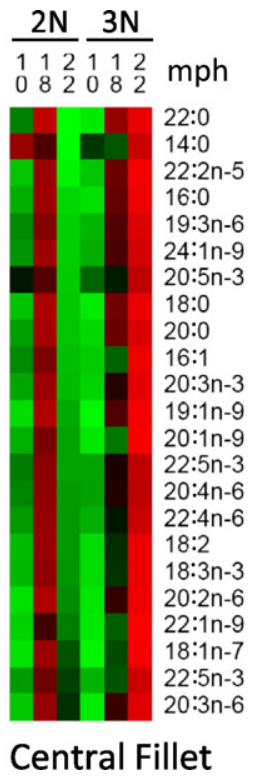

$2 \mathrm{~N} 3 \mathrm{~N}$

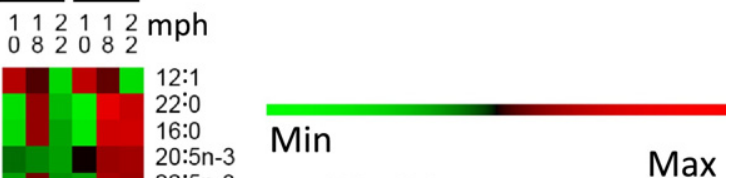

Ventral Fillet
$2 \mathrm{~N} 3 \mathrm{~N}$

$\begin{array}{llllll}1 & 1 & \frac{1}{1} & 1 & 2 \\ 0 & 8 & 2 & 0 & 8 & 2\end{array}$

$22: 5 n-3$
$20: 4 n-6$

22:0

16:0

18:0

$20: 3 n-6$
$20: 1 n-9$

$16: 1$

19:3n-6

$19: 1 \mathrm{n}-9$

$18: 2$

20:0

$18: 1 n-7$

Max

Caudal Fillet

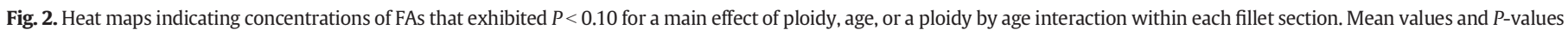
are provided in Supplementary Files 2-5. Green colors indicate minimums and red indicates maximums within each section. Months post hatch (mph). 

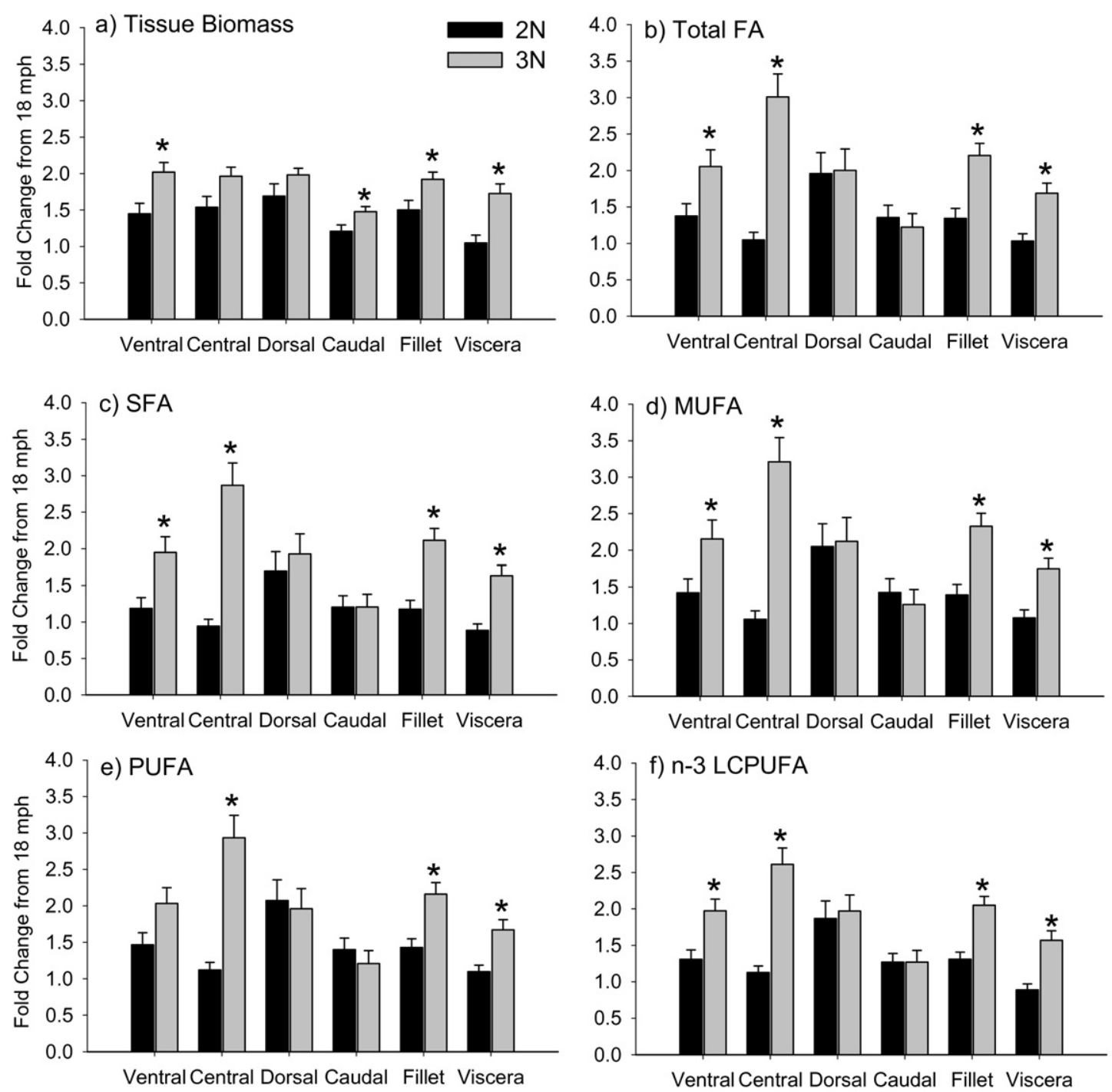

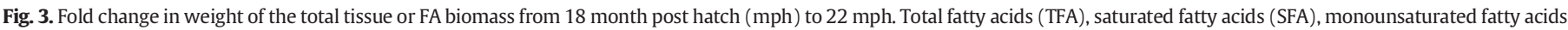
(MUFA), polyunsaturated fatty acids (PUFA), n-3 long-chain PUFA ( $n-3$ LCPUFA). Asterisks indicate that gain differed between $2 \mathrm{~N}$ and $3 \mathrm{~N}$ within a tissue group $(P<0.05)$.

The percent FA content (g per $100 \mathrm{~g}$ tissue) across fillet sections in fish at $22 \mathrm{mph}$ is shown in Fig. 4, as well as percentage point difference from the $18 \mathrm{mph}$ values (in parenthesis). The ventral portion of the fillet had the highest FA content, with the dorsal and caudal sections exhibiting lowest FA levels. Reduced FA deposition during sexual maturation, particularly in central and ventral fillet regions, contributed to $25 \%$ less fat in the $2 \mathrm{~N}$ fillet than the $3 \mathrm{~N}$ fillet (7.4\% vs $9.7 \%$ ), although the difference is not statistically significant $(P=0.073)$.

\subsection{Viscera FA profile}

Whereas concentrations of individual FAs generally increased with age in the fillet, especially in $3 \mathrm{~N}$, there was no such consistent pattern in visceral FAs (Table 4). Concentrations of several SFAs, such as lauric acid (12:0), myristic acid (14:0), and eicosanoic acid (20:0), decreased with age in both $2 \mathrm{~N}$ and $3 \mathrm{~N}$ (Table 4 ) but were not affected by sexual maturation in $2 \mathrm{~N}$. However, palmitic acid (16:0) and stearic acid (18:0), the SFAs of highest abundance, were lowest in $22 \mathrm{mph} 2 \mathrm{~N}$, suggesting that these FAs are preferred as energy substrates during sexual maturation. Concentrations of MUFAs generally increased with age in $2 \mathrm{~N}$ and $3 \mathrm{~N}$, indicating rates of deposition that exceeded the accumulation of viscera biomass. The exceptions were palmitoleic acid (16:1) and nervonic acid (24:1n-9) which decreased in concentration with age. Concentrations of PUFAs in viscera tissue, including n-3 LCPUFA, that were affected by age exhibited reduced concentrations over time. However, some PUFAs were affected by a ploidy $*$ age interaction, including linoleic acid (LA, 18:2n-6), dihomo- $\gamma$-linolenic acid (DGLA, 20:3n-6), docosatetraenoic acid (DTA, 22:4n-6), docosapentaenoic acid (DPA, 22:6n-3); all were elevated in viscera from $22 \mathrm{mph} 2 \mathrm{~N}$ but not $22 \mathrm{mph} 3 \mathrm{~N}$.

The fold-change in viscera and lipid mass in fish from 18 to $22 \mathrm{mph}$ is shown in Fig. 3. Triploid trout gained significantly more viscera mass than $2 \mathrm{~N}$ ( 1.7 vs 1.1 fold increase). The FA gain (1.68 fold) was similar to viscera biomass gain (1.72 fold) in $3 \mathrm{~N}$. However, the abundance of SFAs and $\mathrm{n}-3$ LCPUFAs in $22 \mathrm{mph} 2 \mathrm{~N}$ viscera was 0.88 and 0.84 -fold of $18 \mathrm{mph}$ values, respectively, suggesting a net loss of these FA types throughout sexual maturation.

\subsection{The belly flap and dorsal trimmings represent two additional lipid-rich tissues}

While the concentrations of several FA were affected by age in the dorsal trimmings, there were no ploidy $*$ age interactions, indicating that dorsal FAs likely do not serve as a source of energy during sexual maturation (Supplementary File 6). Similar findings occurred for belly 
Table 3

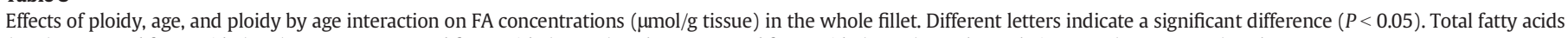
(TFA), saturated fatty acids (SFA), monounsaturated fatty acids (MUFA), polyunsaturated fatty acids (PUFA), $n-3$ long-chain PUFA ( $\mathrm{n}-3$ LCPUFA). Values are means \pm SEM, $n=9$.

\begin{tabular}{|c|c|c|c|c|c|c|c|c|c|c|}
\hline \multirow[t]{2}{*}{ Fatty acid } & \multicolumn{2}{|c|}{10 months } & \multicolumn{2}{|c|}{18 months } & \multicolumn{2}{|c|}{22 months } & \multirow[t]{2}{*}{ Pooled SEM } & \multicolumn{3}{|c|}{$P$-value } \\
\hline & $2 \mathrm{~N}$ & $3 N$ & $2 \mathrm{~N}$ & $3 N$ & $2 \mathrm{~N}$ & $3 N$ & & Ploidy & Age & Ploidy * age \\
\hline $12: 0$ & 0.81 & 0.78 & 0.89 & 0.85 & 0.75 & 0.88 & 0.06 & 0.674 & 0.425 & 0.362 \\
\hline $12: 1$ & 0.66 & 0.66 & 0.68 & 0.67 & 0.46 & 0.51 & 0.09 & 0.806 & 0.065 & 0.939 \\
\hline $14: 0$ & $8.36^{\mathrm{b}}$ & $7.73^{\mathrm{b}}$ & $8.24^{\mathrm{a}}$ & $8.73^{\mathrm{a}}$ & $6.11^{\mathrm{b}}$ & $9.01^{\mathrm{a}}$ & 0.67 & 0.085 & 0.342 & 0.028 \\
\hline $16: 0$ & $37.6^{\mathrm{b}}$ & $33.3^{\mathrm{b}}$ & $55.0^{\mathrm{a}}$ & $57.8^{\mathrm{a}}$ & $42.8^{\mathrm{b}}$ & $64.1^{\mathrm{a}}$ & 4.01 & 0.043 & 0.001 & 0.007 \\
\hline $16: 1$ & 12.7 & 11.6 & 16.7 & 16.6 & 15.5 & 20.3 & 1.43 & 0.271 & 0.007 & 0.078 \\
\hline $18: 0$ & $8.86^{\mathrm{bc}}$ & $7.94^{\mathrm{c}}$ & $13.91^{\mathrm{a}}$ & $14.55^{\mathrm{a}}$ & $11.00^{\mathrm{b}}$ & $15.81^{\mathrm{a}}$ & 0.96 & 0.053 & 0.001 & 0.012 \\
\hline $18: 1 n-9$ & 41.6 & 36.8 & 73.3 & 74.3 & 66.4 & 87.5 & 6.00 & 0.223 & 0.001 & 0.081 \\
\hline $18: 1 n-7$ & 5.26 & 4.95 & 8.88 & 8.78 & 9.02 & 11.21 & 0.67 & 0.256 & 0.001 & 0.113 \\
\hline $18: 2$ & 37.9 & 35.1 & 54.7 & 57.1 & 54.5 & 64.4 & 4.3 & 0.326 & 0.001 & 0.298 \\
\hline $18: 3 n-6$ & 0.83 & 0.80 & 1.04 & 1.09 & 0.90 & 1.12 & 0.07 & 0.154 & 0.002 & 0.187 \\
\hline $18: 3 n-3$ & 4.55 & 4.40 & 6.11 & 6.77 & 6.39 & 7.87 & 0.53 & 0.118 & 0.001 & 0.282 \\
\hline $20: 0$ & $0.38^{\mathrm{b}}$ & $0.34^{\mathrm{b}}$ & $0.50^{\mathrm{a}}$ & $0.52^{\mathrm{a}}$ & $0.41^{\mathrm{b}}$ & $0.54^{\mathrm{a}}$ & 0.03 & 0.124 & 0.001 & 0.026 \\
\hline $20: 1 n-9$ & $3.49^{c}$ & $3.15^{\mathrm{c}}$ & $5.04^{\mathrm{b}}$ & $4.91^{\mathrm{b}}$ & $5.00^{\mathrm{b}}$ & $6.70^{\mathrm{a}}$ & 0.42 & 0.212 & 0.001 & 0.032 \\
\hline $20: 2 n-6$ & 2.54 & 2.52 & 4.10 & 4.12 & 3.85 & 4.61 & 0.30 & 0.265 & 0.001 & 0.305 \\
\hline $20: 3 n-6$ & 1.45 & 1.32 & 2.07 & 2.11 & 2.08 & 2.26 & 0.14 & 0.731 & 0.001 & 0.523 \\
\hline $20: 3 n-3$ & 0.58 & 0.55 & 0.76 & 0.77 & 0.67 & 0.82 & 0.05 & 0.216 & 0.003 & 0.129 \\
\hline $20: 4 n-6$ & 1.84 & 1.81 & 2.26 & 2.37 & 2.13 & 2.61 & 0.21 & 0.287 & 0.031 & 0.478 \\
\hline $20: 5 n-3$ & 5.00 & 4.96 & 5.30 & 5.93 & 4.81 & 6.24 & 0.41 & 0.048 & 0.273 & 0.201 \\
\hline $22: 0$ & $0.15^{\mathrm{b}}$ & $0.12^{\mathrm{b}}$ & $0.22^{\mathrm{a}}$ & $0.23^{\mathrm{a}}$ & $0.15^{\mathrm{b}}$ & $0.24^{\mathrm{a}}$ & 0.02 & 0.095 & 0.001 & 0.007 \\
\hline $22: 1 n-9$ & 0.61 & 0.58 & 0.79 & 0.81 & 0.78 & 1.00 & 0.06 & 0.139 & 0.001 & 0.089 \\
\hline $22: 2 n-5$ & 0.48 & 0.51 & 0.67 & 0.69 & 0.55 & 0.71 & 0.05 & 0.094 & 0.003 & 0.321 \\
\hline $22: 4$ & 0.63 & 0.62 & 0.78 & 0.77 & 0.71 & 0.80 & 0.04 & 0.538 & 0.003 & 0.387 \\
\hline $22: 5 n-3$ & 2.37 & 2.32 & 2.94 & 3.03 & 3.16 & 3.31 & 0.20 & 0.696 & 0.003 & 0.873 \\
\hline $22: 6 n-3$ & 16.9 & 16.1 & 21.1 & 21.4 & 18.0 & 22.5 & 1.2 & 0.148 & 0.001 & 0.092 \\
\hline $24: 0$ & 0.38 & 0.40 & 0.34 & 0.38 & 0.31 & 0.20 & 0.89 & 0.765 & 0.320 & 0.652 \\
\hline $24: 1 n-9$ & 0.59 & 0.57 & 0.74 & 0.77 & 0.61 & 0.77 & 0.05 & 0.145 & 0.004 & 0.133 \\
\hline TFA & 196.1 & 179.7 & 286.6 & 295.8 & 256.8 & 335.9 & 21.6 & 0.161 & 0.001 & 0.073 \\
\hline SFA & $56.6^{\mathrm{b}}$ & $50.6^{\mathrm{b}}$ & $79.1^{\mathrm{a}}$ & $83.1^{\mathrm{a}}$ & $61.6^{\mathrm{b}}$ & $90.7^{\mathrm{a}}$ & 5.7 & 0.050 & 0.001 & 0.009 \\
\hline MUFA & 64.9 & 58.4 & 106.2 & 106.9 & 97.7 & 128.0 & 8.6 & 0.230 & 0.001 & 0.079 \\
\hline PUFA & 71.3 & 67.2 & 96.6 & 100.3 & 92.5 & 111.4 & 7.0 & 0.254 & 0.001 & 0.229 \\
\hline n-3 LCPUFA & 24.6 & 23.9 & 30.1 & 31.2 & 26.4 & 32.8 & 1.9 & 0.142 & 0.003 & 0.155 \\
\hline
\end{tabular}

Bold numbers indicate significance at $P$-values $<0.05$.

flap tissue, in which only two specific FAs, oleic acid (18:1n-9) and vaccenic acid (18:1n-7), increased with age (Supplementary File 7).

\section{Discussion}

Comparisons between FA profiles from sexually maturing $2 \mathrm{~N}$ and sterile $3 \mathrm{~N}$ females indicate how sexual maturation affects the partitioning of lipids across endogenous lipid depots. This study indicates that sexual maturation occurs at the expense of viscera and muscle growth, but while viscera showed no increase in biomass throughout sexual maturation, muscle continued to accumulate, albeit at a slower rate than in sterile $3 \mathrm{~N}$ fish. SFAs appear to serve as the preferred energy source as there was a net loss of SFAs from viscera throughout sexual

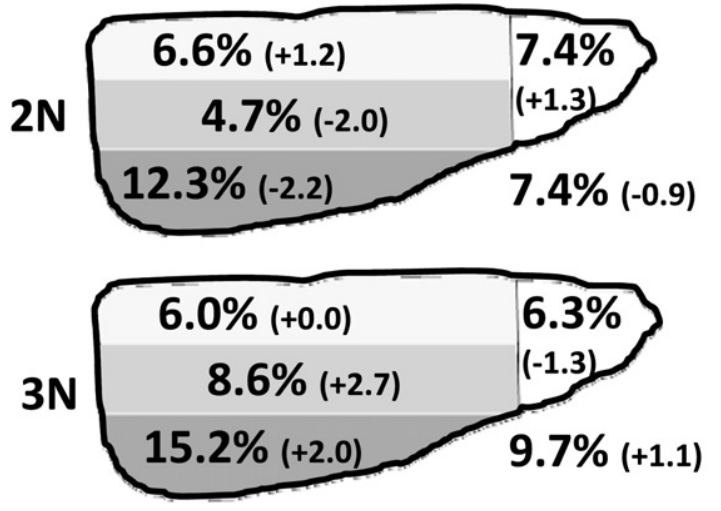

Fig. 4. Percent total FAs in each fillet section at 22 months post hatch (mph) in $2 \mathrm{~N}$ (top) and $3 \mathrm{~N}$ fish (bottom). Percentage point differences from $18 \mathrm{mph}$ levels are shown in parenthesis. Total fillet FAs are shown outside of each fillet. maturation and reduced accumulation in muscle. However, the most novel finding from this study was that effects of sexual maturation on FA partitioning differed between fillet regions. While FA deposition in the dorsal and caudal fillets continued at rates similar to fillet growth, FA deposition in the central fillet essentially ceased, with continued growth predominantly as lean muscle mass. A similar response occurred in the ventral fillet for SFAs only. These effects are likely a result of both increased mobilization of stored FAs and redirection of FAs away from deposition in central and ventral fillets towards support of gonad development.

Much of what is known regarding lipid partitioning responses in salmonids is based on responses observed in an entire tissue type, i.e.: red versus white muscle, belly flap, viscera, etc., rather than subsections of specific tissues as in the current study (Kiessling et al., 1991, 2001; Manor et al., 2012, 2014). However, prior characterizations of the adipocyte and lipid distribution patterns and enzyme activity across the fillet have increased our understanding of the lipid partitioning response. Changes in enzyme activities in epaxial white muscle suggest sexually maturing trout have an increased reliance upon fat for energy, concomitant with a decrease in glycolytic capacity (Kiessling et al., 1995). This response was most dramatic in the central fillet and decreased in intensity towards the dorsal region. Combining these findings with those from the current study support localized up-regulation of FA utilization in the central fillet, contributing to reduced FA deposition rates and decreased FA content in this section. These effects diminished towards the dorsal fillet where FA deposition continued to occur. It has been suggested that the advantage provided by region-specific regulation of FA partitioning is the preservation of muscle contractile patterns that themselves differ across fillet regions (Kiessling et al., 1995).

In teleosts, skeletal muscle tissue is comprised of both red and white muscle, with a longitudinal band of superficial red muscle along the midline of each side of the fish. The primary function of red muscle is 
Table 4

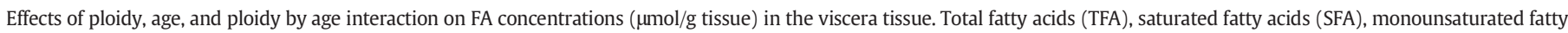
acids (MUFA), polyunsaturated fatty acids (PUFA), $\mathrm{n}-3$ long-chain PUFA ( $\mathrm{n}-3$ LCPUFA). Different letters indicate a significant difference $(P<0.05)$. Values are means \pm SEM, $\mathrm{n}=9$.

\begin{tabular}{|c|c|c|c|c|c|c|c|c|c|c|}
\hline \multirow[t]{2}{*}{ Fatty acid } & \multicolumn{2}{|c|}{10 months } & \multicolumn{2}{|c|}{18 months } & \multicolumn{2}{|c|}{22 months } & \multirow[t]{2}{*}{ Pooled SEM } & \multicolumn{3}{|l|}{$P$-value } \\
\hline & $2 \mathrm{~N}$ & $3 \mathrm{~N}$ & $2 \mathrm{~N}$ & $3 \mathrm{~N}$ & $2 \mathrm{~N}$ & $3 N$ & & Ploidy & Age & Ploidy $*$ age \\
\hline $12: 0$ & 5.94 & 6.21 & 4.09 & 4.17 & 3.17 & 3.65 & 0.24 & 0.263 & 0.001 & 0.697 \\
\hline $12: 1$ & $2.67^{\mathrm{a}}$ & $2.61^{\mathrm{a}}$ & $1.92^{\mathrm{b}}$ & $1.54^{\mathrm{b}}$ & $0.81^{\mathrm{c}}$ & $1.46^{\mathrm{b}}$ & 0.20 & 0.598 & 0.001 & 0.030 \\
\hline $14: 0$ & 380.6 & 373.0 & 251.1 & 249.9 & 229.01 & 226.7 & 5.8 & 0.526 & 0.001 & 0.798 \\
\hline $16: 0$ & $1452^{\mathrm{a}}$ & $1400^{\mathrm{a}}$ & $1414^{\mathrm{a}}$ & $1441^{\mathrm{a}}$ & $1178^{\mathrm{b}}$ & $1379^{a}$ & 29 & 0.012 & 0.001 & 0.001 \\
\hline $16: 1$ & 596.6 & 577.1 & 530.8 & 514.2 & 543.1 & 522.8 & 13.3 & 0.082 & 0.001 & 0.975 \\
\hline $18: 1 n-9$ & $371.2^{\mathrm{ab}}$ & $358.4^{\mathrm{b}}$ & $378.4^{\mathrm{a}}$ & $389.3^{\mathrm{a}}$ & $324.2^{\mathrm{c}}$ & $376.1^{\mathrm{a}}$ & 7.5 & 0.006 & 0.001 & 0.001 \\
\hline $18: 1 n-7$ & 1923 & 1832 & 2281 & 2246 & 2352 & 2237 & 46 & 0.036 & 0.001 & 0.655 \\
\hline $18: 2$ & 259.7 & 260.7 & 304.2 & 287.9 & 296.4 & 305.4 & 12.2 & 0.943 & 0.015 & 0.508 \\
\hline $18: 3 n-6$ & $1840^{\mathrm{b}}$ & $1818^{\mathrm{b}}$ & $1842^{\mathrm{b}}$ & $1803^{b}$ & $2077^{\mathrm{a}}$ & $1759^{\mathrm{b}}$ & 45 & 0.015 & 0.064 & 0.006 \\
\hline $18: 3 n-3$ & 21.9 & 22.0 & 19.2 & 20.0 & 17.5 & 17.6 & 0.7 & 0.398 & 0.001 & 0.708 \\
\hline $18: 1 n-9$ & 206.1 & 205.5 & 203.8 & 200.9 & 207.0 & 195.7 & 5.3 & 0.328 & 0.726 & 0.789 \\
\hline $20: 0$ & 27.4 & 27.7 & 26.0 & 25.7 & 23.9 & 23.9 & 0.9 & 0.841 & 0.001 & 0.090 \\
\hline $20: 1 n-9$ & 137.1 & 126.3 & 142.3 & 144.0 & 167.4 & 174.3 & 4.3 & 0.880 & 0.001 & 0.093 \\
\hline $20: 2 n-6$ & 130.2 & 134.5 & 132.5 & 130.5 & 134.6 & 129.4 & 3.5 & 0.784 & 0.962 & 0.437 \\
\hline $20: 3 n-6$ & $44.7^{\mathrm{bc}}$ & $42.7^{c}$ & $47.5^{\mathrm{b}}$ & $46.0^{\mathrm{bc}}$ & $52.9^{\mathrm{a}}$ & $44.4^{\mathrm{bc}}$ & 1.5 & 0.002 & 0.003 & 0.024 \\
\hline $20: 3 n-3$ & 13.6 & 13.6 & 13.7 & 12.9 & 11.4 & 12.0 & 0.6 & 0.942 & 0.004 & 0.362 \\
\hline $20: 4 n-6$ & 63.8 & 66.0 & 52.0 & 52.0 & 46.6 & 43.6 & 1.6 & 0.902 & 0.001 & 0.309 \\
\hline $20: 5 n-3$ & 200.2 & 205.3 & 142.6 & 148.4 & 111.1 & 129.3 & 4.9 & 0.018 & 0.001 & 0.283 \\
\hline $22: 0$ & 6.85 & 6.55 & 6.51 & 6.59 & 6.65 & 6.11 & 0.27 & 0.248 & 0.423 & 0.643 \\
\hline $22: 1 n-9$ & 16.9 & 16.1 & 16.2 & 16.1 & 19.2 & 17.2 & 0.8 & 0.147 & 0.008 & 0.424 \\
\hline $22: 4$ & $12.6^{\mathrm{a}}$ & $12.7^{\mathrm{a}}$ & $11.4^{\mathrm{b}}$ & $11.0^{\mathrm{bc}}$ & $13.7^{\mathrm{a}}$ & $10.3^{c}$ & 0.4 & 0.003 & 0.021 & 0.001 \\
\hline $22: 5 n-3$ & $88.3^{\mathrm{a}}$ & $89.7^{\mathrm{a}}$ & $76.9^{\mathrm{b}}$ & $76.0^{\mathrm{b}}$ & $93.3^{\mathrm{a}}$ & $74.8^{\mathrm{b}}$ & 2.5 & 0.005 & 0.001 & 0.009 \\
\hline $22: 6 n-3$ & 468.7 & 461.9 & 432.2 & 409.7 & 350.8 & 371.5 & 10.3 & 0.747 & 0.001 & 0.122 \\
\hline $24: 0$ & $3.76^{a}$ & $3.71^{\mathrm{a}}$ & $3.04^{\mathrm{c}}$ & $3.02^{c}$ & $3.33^{\mathrm{b}}$ & $2.87^{c}$ & 0.07 & 0.008 & 0.001 & 0.015 \\
\hline $24: 1 n-9$ & 12.4 & 12.7 & 11.1 & 11.5 & 11.0 & 11.1 & 0.4 & 0.410 & 0.002 & 0.907 \\
\hline TFA & 8288 & 8077 & 8346 & 8253 & 8276 & 8077 & 145 & 0.200 & 0.672 & 0.921 \\
\hline SFA & $2248^{a}$ & $2176^{\mathrm{ab}}$ & $2084^{\mathrm{bc}}$ & $2121^{\mathrm{bc}}$ & $1769^{d}$ & $2019^{c}$ & 41 & 0.028 & 0.001 & 0.004 \\
\hline MUFA & 2949 & 2827 & 3288 & 3221 & 3390 & 3269 & 63 & 0.053 & 0.001 & 0.877 \\
\hline PUFA & 3090 & 3072 & 2974 & 2911 & 3116 & 2788 & 64 & 0.210 & 0.087 & 0.093 \\
\hline n-3 LCPUFA & 773 & 772 & 667 & 650 & 575 & 593 & 15 & 0.993 & 0.001 & 0.558 \\
\hline
\end{tabular}

Bold numbers indicate significance at $P$-values $<0.05$.

to provide movement to support efficient, sustained swimming activity while white muscle is predominantly responsible for short bursts of speed (Coughlin, 2002; Muller and van Leeuwen, 2006). As expected, red muscle contains high levels of mitochondria that preferentially utilize FAs, especially saturated SFAs, as substrates for aerobic oxidation (Kiessling and Kiessling, 1993). Retaining adequate lipid levels in this tissue, which are 3-10 times higher than white muscle (Aursand et al., 1994; Zhou et al., 1995), are essential for proper red muscle function to sustain swimming activity. Lipid-rich myosepta extend from the central white muscle through to the peripheral red muscle tissue (Zhou et al., 1995), so it is likely most efficient to mobilize lipids from the central fillet region as it is in closest proximity to red muscle. Therefore, the localized up-regulation of lipid oxidation in the central fillet to support red muscle function may have contributed to reductions in lipid concentrations during sexual maturation.

Despite a ploidy $*$ age interaction in the central fillet that affected nearly every FA species, when considering changes in the whole fillet and viscera, there appeared to be an increased reliance upon SFAs during sexual maturation. This is evidenced by a ploidy $*$ age interaction for most SFAs in the whole fillet, particularly the central fillet, and viscera. These findings are in agreement with previous literature citing reductions in these FA species during spawning in salmonids (Manor et al., 2012; Ribeiro et al., 2012). The preference of red muscle for SFAs (Kiessling and Kiessling, 1993) as an energy source may be directly involved in this response, as is the high metabolic demand associated with gonad development.

Although the accumulation of total FA in viscera essentially ceased in sexually maturing $2 \mathrm{~N}$ (18-22 mph), concentrations of several PUFAs were at a lifetime highest at $22 \mathrm{mph}$. These lipids included LA, which is the second most abundant FA, representing 25\% of total visceral FA, DGLA, DTA, and DPA. An elevation of LA in visceral tissue has been previously reported (Manor et al., 2012). These findings suggest there is a preference against mobilizing these FA species from the viscera.
Two of these FAs, LA and DGLA, can be converted to arachidonic acid (20:4n-6), which itself is a precursor of a number of eicosanoids. Elevated visceral concentrations of LA and DGLA may represent a downregulation of the eicosanoid pathway in the sexually maturing female that may have negative effects on egg quality and reproductive success.

FAs are primarily stored as triacylglycerols (TAG) that represent approximately $80-88 \%$ and $>99 \%$ of total lipids in white muscle and viscera fat, respectively (Kiessling et al., 2001). Most of the remaining FAs are esterified in the phospholipids (Kiessling et al., 2001), which are a major component of lipid membranes and differ in lipid composition as they favor the unsaturated lipid species. Although this analysis did not differentiate between the TAG and phospholipid types, $>80 \%$ of the FAs in muscle are in the TAG form, so the lipid profile is largely representative of the TAG fraction. These findings are in general agreement with previous studies (Manor et al., 2014, 2012; Ribeiro et al., 2012; Testi et al., 2006; Usydus et al., 2011), although there is considerable variation in DHA levels among these studies that could result from differences in dietary lipid profiles.

During sexual maturation lipids serve as an energy source but also as substrates for vitellogenin synthesis and deposition in the developing oocytes. While MUFAs are generally the FA class of highest concentration in muscle and viscera tissue of larger fish ( $\geq 18 \mathrm{mph}$ ), PUFAs dominate in the developing oocytes, particularly as DHA (Manor et al., 2014, 2012; Ribeiro et al., 2012). DHA has established roles in mammalian embryo development, brain development, and maintenance of cardiac health (Brenna and Carlson, 2014; Raatz and Bibus, 2016) and studies suggest DHA is similarly essential for growth and neural development in fish embryos (Izquierdo et al., 2013; Morais et al., 2011). Despite different levels of nutrient and/or feed intake that affect the lipid profile of the mature oocyte, DHA concentrations remain stable (Manor et al., 2014), as does the oocyte proximate composition (Washburn et al., 1990), suggesting that deposition of the appropriate nutrients in the developing oocyte is a physiological priority. 
N-3 LCPUFAs are acknowledged for their beneficial effects on inflammatory mechanisms (Calder, 2015). Salmonids like rainbow trout and Atlantic salmon are recognized as having high EPA and DHA content, both due to consumption of diets with relatively high levels of fish oil (Turchini et al., 2009) and the ability to convert medium-chain n-3 lipids to n-3 LCPUFA (Buzzi et al., 1996). Consumption of Atlantic salmon twice weekly by adults has a positive, dose-dependent effect on indices of cardiovascular disease (Raatz et al., 2013), suggesting that comparable doses of n-3 LCPUFA from rainbow trout will produce similar effects. When considering the fillet as a whole, $3 \mathrm{~N}$ rainbow trout exhibited higher levels of EPA than 2N, regardless of age, and a similar effect was detected in viscera tissue. Also worth noting is that the EPA concentrations were at numerically lowest levels in fillet and viscera of $22 \mathrm{mph} 2 \mathrm{~N}$, indicating the negative impact that sexual maturation has on this lipid. This decrease likely contributes to a main effect of ploidy on EPA concentrations that favor the $3 \mathrm{~N}$. Regardless, the fillet, particularly the ventral and central fillet regions, in larger 3Ns (>18 mph) represents the product(s) with the numerically greatest EPA and DHA concentrations and therefore could be viewed as the products with optimal benefits for human health. Nevertheless, the $10 \mathrm{mph}$ rainbow trout, regardless of ploidy, is still considered a high n-3 LCPUFA fish valuable for human consumption.

\section{Conclusions}

Our data suggest that physiological mechanisms affecting nutrient deposition and growth in the fillet are differentially regulated across fillet regions by maturation-related signals. SFAs are preferentially targeted for mobilization during sexual maturation, suggesting that an energy deficiency is initiating lipid repartitioning, rather than an increased requirement for a specific lipid species essential for gonad development. Therefore, increasing the energy content of broodstock diets may help alleviate reductions in lipid stores and improve the ability of the $2 \mathrm{~N}$ female to recover for additional spawning. Due to the absence of gonad development, female $3 \mathrm{~N}$ rainbow trout continue to deposit lipids with age and are therefore valuable for production of large, high-quality fillets with greater n-3 LCPUFA content than the traditional pan-size rainbow trout.

\section{Acknowledgments}

The authors acknowledge invaluable technical contributions from NCCCWA technicians Josh Kretzer and Lisa Radler and GFHNRC technicians Eric Strubeck, Joseph Idso, Deborah Johnson, and Michael Storandt. Animal caretaking contributions from Kyle Jenkins and Jenea McGowan are also acknowledged. Mention of trade names is solely to provide accurate information and does not imply endorsement by the USDA. The USDA is an equal opportunity employer and provider. This study was supported by funding from USDA-NIFA (Award No 201467017-21758)

\section{Appendix A. Supplementary data}

Supplementary data to this article can be found online at http://dx. doi.org/10.1016/j.aquaculture.2017.03.012.

\section{References}

Albert, C.M., Hennekens, C.H., O'Donnell, C.J., Ajani, U.A., Carey, V.J., Willett, W.C., Ruskin, J.N., Manson, J.E., 1998. Fish consumption and risk of sudden cardiac death. JAMA 279, 23-28.

Allen, S.K., 1983. Flow cytometry: assaying experimental polyploid fish and shellfish. Aquaculture 33, 317-328.

Aursand, M., Bleivik, B., Rainuzzo, J.R., Jorgensen, L., Mohr, V., 1994. Lipid distribution and composition of commercially farmed Atlantic salmon (Salmo-salar). J. Sci. Food Agric. 64, 239-248.

Aussanasuwannakul, A., Kenney, P.B., Weber, G.M., Yao, J., Slider, S.D., Manor, M.L., Salem, M., 2011. Effect of sexual maturation on growth, fillet composition, and texture of female rainbow trout (Oncorhynchus mykiss) on a high nutritional plane. Aquaculture $317,79-88$.

Blanchet, C., Lucas, M., Julien, P., Morin, R., Gingras, S., Dewailly, E., 2005. Fatty acid composition of wild and farmed Atlantic salmon (Salmo salar) and rainbow trout (Oncorhynchus mykiss). Lipids 40, 529-531.

Brenna, J.T., Carlson, S.E., 2014. Docosahexaenoic acid and human brain development: evidence that a dietary supply is needed for optimal development. J. Hum. Evol. 77, 99-106.

Burr, M.L., Fehily, A.M., Gilbert, J.F., Rogers, S., Holliday, R.M., Sweetnam, P.M., Elwood, P.C., Deadman, N.M., 1989. Effects of changes in fat, fish, and fibre intakes on death and myocardial reinfarction: diet and reinfarction trial (DART). Lancet 2, 757-761.

Buzzi, M., Henderson, R.J., Sargent, J.R., 1996. The desaturation and elongation of linolenic acid and eicosapentaenoic acid by hepatocytes and liver microsomes from rainbow trout (Oncorhynchus mykiss) fed diets containing fish oil or olive oil. BBA-Lipids Lipid Metab. 1299, 235-244.

Calder, P.C., 2006. n-3 polyunsaturated fatty acids, inflammation, and inflammatory diseases. Am. J. Clin. Nutr. 83, 1505S-1519S

Calder, P.C., 2010. Omega-3 fatty acids and inflammatory processes. Nutrients 2, 355-374.

Calder, P.C., 2015. Marine omega-3 fatty acids and inflammatory processes: effects, mechanisms and clinical relevance. BBA-Mol. Cell Biol. Lipids 1851, 469-484.

Cleveland, B.M., Kenney, P.B., Manor, M.L., Weber, G.M., 2012. Effects of feeding level and sexual maturation on carcass and fillet characteristics and indices of protein degradation in rainbow trout (Oncorhynchus mykiss). Aquaculture 338, 228-236.

Coughlin, D.J., 2002. Aerobic muscle function during steady swimming in fish. Fish Fish. 3, 63-78.

Daviglus, M.L., Stamler, J., Orencia, A.J., Dyer, A.R., Liu, K., Greenland, P., Walsh, M.K., Morris, D., Shekelle, R.B., 1997. Fish consumption and the 30-year risk of fatal myocardial infarction. N. Engl. J. Med. 336, 1046-1053.

Folch, J., Lees, M., Sloane Stanley, G.H., 1957. A simple method for the isolation and purification of total lipides from animal tissues. J. Biol. Chem. 226, 497-509.

Hershberger, W., Hostuttler, M., 2007. Protocols for more effective induction of tetraploid rainbow trout. N. Am. J. Aquac. 69, 367-372.

Izquierdo, M.S., Scolamacchia, M., Betancor, M., Roo, J., Caballero, M.J., Terova, G., Witten, P.E., 2013. Effects of dietary DHA and alpha-tocopherol on bone development, early mineralisation and oxidative stress in Sparus aurata (Linnaeus, 1758) larvae. Br. J. Nutr. 109, 1796-1805.

Jonsson, N., Jonsson, B., Hansen, L.P., 1997. Changes in proximate composition and estimates of energetic costs during upstream migration and spawning in Atlantic salmon Salmo salar. J. Anim. Ecol. 66, 425-436.

Katikou, P., Hughes, S.I., Robb, D.H.F., 2001. Lipid distribution within Atlantic salmon (Salmo salar) fillets. Aquaculture 202, 89-99.

Kiessling, K.H., Kiessling, A., 1993. Selective utilization of fatty-acids in rainbow-trout (Oncorhynchus-mykiss Walbaum) red muscle mitochondria. Can. J. Zool. 71, 248-251.

Kiessling, A., Asgard, T., Storebakken, T., Johansson, L., Kiessling, K.H., 1991. Changes in the structure and function of the epaxial muscle of rainbow-trout (Oncorhynchus-mykiss) in relation to ration and age. 3. Chemical-composition. Aquaculture 93, 373-387.

Kiessling, A., Larsson, L., Kiessling, K.H., Lutes, P.B., Storebakken, T., Hung, S.S.S., 1995. Spawning induces a shift in energy metabolism from glucose to lipid in rainbow trout white muscle. Fish Physiol. Biochem. 14, 439-448.

Kiessling A., Pickova, J. Johansson, L, Asgard, T., Storebakken, T., Kiessling K.H., 2001. Changes in fatty acid composition in muscle and adipose tissue of farmed rainbow trout (Oncorhynchus mykiss) in relation to ration and age. Food Chem. 73, 271-284.

Kinsella, J.E., Shimp, J.L., Mai, J., Weihrauch, J., 1977. Fatty-acid content and composition of freshwater finfish. J. Am. Oil Chem. Soc. 54, 424-429.

Kris-Etherton, P.M., Harris, W.S., Appel, L.J., Comm, A.N., 2003a. Omega-3 fatty acids and cardiovascular disease - new recommendations from the American Heart Association. Arterioscler. Thromb. Vasc. 23, 151-152.

Kris-Etherton, P.M., Harris, W.S., Appel, L.J., Comm, N., 2003b. Fish consumption, fish oil, omega-3 fatty acids, and cardiovascular disease. Arterioscler. Thromb. Vasc. 23, E20-E31.

Lincoln, R.F., Scott, A.P., 1983. Production of all-female triploid rainbow-trout. Aquaculture 30, 375-380.

Manor, M.L., Weber, G.M., Salem, M., Yao, J.B., Aussanasuwannakul, A., Kenney, P.B., 2012. Effect of sexual maturation and triploidy on chemical composition and fatty acid content of energy stores in female rainbow trout, Oncorhynchus mykiss. Aquaculture 364, 312-321.

Manor, M.L., Weber, G.M., Cleveland, B.M., Kenney, P.B., 2014. Effects of feeding level and sexual maturation on fatty acid composition of energy stores in diploid and triploid rainbow trout (Oncorhynchus mykiss). Aquaculture 418, 17-25.

Morais, S., Mourente, G., Ortega, A., Tocher, J.A., Tocher, D.R., 2011. Expression of fatty acyl desaturase and elongase genes, and evolution of DHA:EPA ratio during development of unfed larvae of Atlantic bluefin tuna (Thunnus thynnus L.). Aquaculture 313, 129-139.

Muller, U.K., van Leeuwen, J.L., 2006. Undulatory fish swimming: from muscles to flow. Fish Fish. 7, 84-103.

Palmeri, G., Turchini, G.M., De Silva, S.S., 2007. Lipid characterisation and distribution in the fillet of the farmed Australian native fish, Murray cod (Maccullochella peelii peelii). Food Chem. 102, 796-807.

Picklo, M.J., Murphy, E.J., 2016. A high-fat, high-oleic diet, but not a high-fat, saturated diet, reduces hepatic alpha-linolenic acid and eicosapentaenoic acid content in mice. Lipids 51, 537-547.

Raatz, S., Bibus, D., 2016. Fish and Fish Oil in Health and Disease Prevention. Academic Press, London, UK

Raatz, S.K., Rosenberger, T.A., Johnson, L.K., Wolters, W.W., Burr, G.S., Picklo, M.J., 2013. Dose-dependent consumption of farmed Atlantic salmon (Salmo salar) increases plasma phospholipid n-3 fatty acids differentially. J. Acad. Nutr. Diet. 113, 282-287. 
Ribeiro, C.S., Gomes, A.D., Vieira, V.A.R.O., Tabata, Y.A., Takahashi, N.S., Moreira, R.G., 2012 The effect of ploidy on the fatty acid profile during the reproductive cycle of female rainbow trout (Oncorhynchus mykiss). Aquac. Int. 20, 1117-1137.

Testi, S., Bonaldo, A., Gatta, P.P., Badiani, A., 2006. Nutritional traits of dorsal and ventral fillets from three farmed fish species. Food Chem. 98, 104-111.

Tocher, D., 2003. Metabolism and functions of lipids and fatty acids in fish. Rev. Fish. Sci. 11, 107-184.

Toussaint, C., Fauconneau, B., Medale, F., Collewet, G., Akoka, S., Haffray, P., Davenel, A 2005. Description of the heterogeneity of lipid distribution in the flesh of brown trout (Salmo trutta) by MR imaging. Aquaculture 243, 255-267.

Turchini, G.M., Torstensen, B.E., Ng, W.K., 2009. Fish oil replacement in finfish nutrition. Rev. Aquac. 1, 10-57.

Tveranger, B., 1985. Variation in growth rate, liver weight and body composition at first sexual maturity in rainbow trout. Aquaculture 49, 89-99.
Usydus, Z., Szlinder-Richert, J., Adamczyk, M., Szatkowska, U., 2011. Marine and farmed fish in the Polish market: comparison of the nutritional value. Food Chem. 126, 78-84. Vykoukal, D., Davies, M.G., 2011. Vascular biology of metabolic syndrome. J. Vasc. Surg. 54 819-831.

Washburn, B., Frye, D., Hung, S., Doroshov, S., Conte, F., 1990. Dietary effects on tissue composition, oogenesis and the reproductive performance of female rainbow trout (Oncorhynchus mykiss). Aquaculture 90, 179-195.

Weber, G.M., Hostuttler, M.A., Cleveland, B.M., Leeds, T.D., 2014. Growth performance comparison of intercross-triploid, induced triploid, and diploid rainbow trout. Aquaculture 433, 85-93.

Wu, T.H., Bechtel, P.J., 2008. Salmon by-product storage and oil extraction. Food Chem. $111,868-871$.

Zhou, S.Y., Ackman, R.G., Morrison, C., 1995. Storage of lipids in the myosepta of Atlantic salmon (Salmo-salar). Fish Physiol. Biochem. 14, 171-178. 